\title{
Comparative Analysis of Different Combinations of Composting and Testing of Soil Physical Properties
}

\author{
Tej Kumar Nepal ${ }^{1, *}$, Ugyen Dorji ${ }^{2}$, Yeshi Nidup ${ }^{2}$, Chencho Wangdi ${ }^{2}$, Kelzang Tshering $^{2}$, Tashi Wangdi ${ }^{2}$
}

\author{
${ }^{1}$ Student, School of Ecology and Environment Studies, Nalanda University, Rajgir, Bihar, India \\ ${ }^{2}$ Freelance Researcher, Thimphu, Bhutan \\ *Corresponding author: tejkumarnepal97@gmail.com
}

\begin{abstract}
During composting process, soils undergo many changes in their physical, chemical and biological properties. Composting has been widely known as an aerobic process during which organic matter is decomposed to humus like substances broken into many organic materials or compounds. The project aims to compare and analyze different combination of composting that yield different properties and nature of soils, and testing their soil physical properties. Dug three compost pits each $1.5 \mathrm{~m}$ in depth, labeled compost pit A consisting of potato peels the only kitchen waste most common around the college hostels, compost pit B consisting of leaf litter and other garden trimmings and compost pit $\mathrm{C}$ consisting of cow dung and the other as a controlled experiment with no composting practices.
\end{abstract}

Keywords: Soil, parameters, pit, composting, analysis, properties

\section{Introduction}

Soil can be defined as the unconsolidated mineral or organic material on the surface of the earth arising from a particular parent material that has been subjected to and shows the effects of climate macro and micro-organisms, the topography of its location in the landscape, and time (Keesstra, et al., 2016). Soils are vital for life on earth, though it is not an infinite resource, meaning its loss and degradation is not recoverable within a human lifespan (Brevik, et al., 2015). Soil supports the growth of higher plants, mainly providing a medium for plant roots and to supply nutrient elements to the plant (Hayat, Ali, Amara, Khalid, \& Ahmed, 2010). Soil properties are the principal factor controlling the fate of water in the hydrologic system (Perk, 2013). Soil functions as nature's recycling systemthe waste products and dead bodies of plants, animals, and people are assimilated and their basic elements are made available for reuse by the next generation of life (Davidson \& Janssens, 2016). Soil also provides habitats to living organisms of unimaginable numbers and diversity, from small mammals and reptiles to tiny insects to microscopic cells (Wolters, 2001). In human-built ecosystems, soil plays an important role as an engineering medium (Bender, Wagg, \& Heijden, 2016). Its physical properties in general comprises of: soil color - due to minerals present and organic matter content, soils can exhibit a wide range of grey, black, white, browns, yellows, green and red colors even during weather and topographical factors as well (Melville \& Atkinson, 1985); temperature - temperature is one of the key factors affecting the composting process. During microbial breakdown of organic matter, compost heat is produced as a by product (Nakasaki, Shoda, \& Kubota, 1985); soil pH - it is often expressed as the measure of hydrogen ion concentration or the measure of acidity and alkalinity of a solution or a sample (Stevens, Laughlin, \& Malone, 1998). In addition it is also one of the decisive factors affecting metal solubility, plant growth, plant nutrient uptake and movement and many other reaction (Epstein, 1997); moisture content - it is the quality of water contained in the soil. It forms a major part of plant itself along with it is essential for physiological activities, acts as a solvent and nutrient carrier and maintains the turbidity of plants (Lang \& Smith, 2007); soil texture - due to physical weathering it results in a wide range in size of soil particles from stones to gravel and finally to sand, silt and small clay particles (Jones, 1983); bulk density - it is an indicator of soil compaction and soil health. It affects infiltration, rooting depth, available water capacity, soil porosity, plant nutrient availability and soil micro-organism activity which influence the key soil processes and productivity (Williams, Ahuja, \& Naney, 1992); organic carbon - it is a measurable component of soil organic matter which consists of relatively available carbon in the form of fresh plant remains, or animal residues and various stages of decomposition of cells and tissues of other soil microorganisms (Chan, 2001). Its importance constitutes of determining soil fertility, a stimulant of natural carbon cycle, promoting the structural, biological and physical health of soil and a buffer against harmful substances (Quine \& Zhang, 2002). 
During composting process, soil undergoes many changes in their physical, chemical and biological properties (Cooperband, 2000). Composting has been widely known as an aerobic process during which organic matter is decomposed to humus like substances broken into many organic materials or compounds. According to (Epstein, 1997) compost production is considered an economic and environmentally friendly means to reduce waste especially home-made, kitchen organic waste going into landfills and other forms of dumping sites. It has also been shown that composting can have another beneficial effect such as removal of pathogen inoculant or weed seeds, as a method of erosion control and a source of nutrient for sustainable re-vegetation of degraded soils (Jiang, Wang, Haiyan, Labzovskii, \& Liu, 2019). Therefore, this research mainly focuses on comparing and analysis of different combination of composting and testing their soil physical properties.

\subsection{Aim}

Comparison and analysis of different combination of composting that yield different properties and nature of soils, and testing their soil physical properties.

\subsection{Objective}

To test the soil properties from each combination of composting practices that we have created, compost pits comprising of potato peels, leaf litter and cow dung separately. To compare and determine the hypothesis towards confirming which combination of composting is faster and more efficient depending on our results. To conclude upon our result and show which is best option for managing waste generated from our household, while also confirming simple ways to utilize soil management in and around us.

\section{Methodology}

\subsection{Study Methods}

We have opted to dig three compost pits measuring $1.5 \mathrm{~m}$ in depth, labeled compost pit A consisting of potato peels - the only kitchen waste most common around the college hostels, compost pit B consisting of leaf litter and other garden trimmings and compost pit $\mathrm{C}$ consisting of cow dung and the other as a controlled experiment with no composting practices. The various combination of compost in each pit was then added with some layers of soil and the pits were covered with plank to avoid contamination of the compost during rainfall.

\subsection{Study Area}

The study was conducted near one of the hostels (Degree Hostel VI) of Sherubtse College under Royal University of Bhutan. The project was part of requirement of undergraduate course assessment. For the digging of compost pit and collection of our soil sample, we chose a site near DH 6 (Degree Hostel 6) as it was near the college vicinity therefore eliminating our time constraints while attending the compost progress.

\subsection{Data collection and Laboratory Work (Instruments used)}

The primary data for this study was collected by doing laboratory experiments in an Environmental Science Laboratory (ESL), Sherubtse College, Royal University of Bhutan. To conduct the comparative analysis of soil properties from different combination of compost pits, collection of soil samples was our top priority. With the samples, various physical parameters of the soil were tested;

a) Soil Color - by referring to Munsell's Soil Color book.

b) Soil $\mathrm{pH}$ - by using digital $\mathrm{pH}$ meter.

c) Soil texture - by applying sieve method and deducing the result by referring Soil Texture Triangle

d) Moisture content - by applying weighing method and calculating it by Gravimetric method.

e) Organic Carbon - by implementing Walkley-Black Method.

\subsection{Update (Progress Check)}

We started our work by digging three compost pits and would realize that with different combinations of composting implemented, all three of the pits would require time to decompose with the soil and yield good compost. So, we tended to them every week, made sure to mix them, cover them from the rain and much foggy weather. Added little bit of water, and exposed it to direct sunlight at all times. Until 4 weeks and 4 days later our compost pit showed some signs of decomposition especially for leaf litter and cow dung pits but for potato peels, the rate of decomposition had been much slow as we noticed potato peels still fresh and thick that we needed another additional days for it to be turned into a fully perfect compost. 


\subsection{Data and Observations}

2.5.1. Soil Color

\begin{tabular}{|l|l|l|l|c|}
\hline $\begin{array}{l}\text { Compost } \\
\text { combinations }\end{array}$ & $\begin{array}{l}\text { Potato Compost } \\
\text { Pit (A) }\end{array}$ & $\begin{array}{l}\text { Leaf Compost } \\
\text { Pit (B) }\end{array}$ & $\begin{array}{l}\text { Cow dung Compost } \\
\text { Pit (C) }\end{array}$ & $\begin{array}{c}\text { Controlled } \\
\text { experiment }\end{array}$ \\
\hline Color & Yellowish Brown & Dark Brown & Very dark brown & Brownish yellow \\
\hline
\end{tabular}

\subsubsection{Soil pH}

\begin{tabular}{|c|c|c|c|c|}
\hline $\begin{array}{l}\text { Compost } \\
\text { combinations }\end{array}$ & $\begin{array}{l}\text { Compost Pit } \\
\text { A }\end{array}$ & $\begin{array}{l}\text { Compost Pit } \\
\text { B }\end{array}$ & $\begin{array}{l}\text { Compost Pit } \\
\text { C }\end{array}$ & $\begin{array}{l}\text { Controlled } \\
\text { experiment }\end{array}$ \\
\hline pH value & 7.1 & 7.1 & 7.6 & 7.3 \\
\hline
\end{tabular}

\subsubsection{Soil Texture}

\begin{tabular}{|c|c|c|c|c|}
\hline $\begin{array}{l}\text { Compost } \\
\text { Combinations }\end{array}$ & $\begin{array}{l}\text { Compost Pit } \\
\text { A }\end{array}$ & $\begin{array}{l}\text { Compost Pit } \\
\text { B }\end{array}$ & $\begin{array}{l}\text { Compost Pit } \\
\text { C }\end{array}$ & $\begin{array}{l}\text { Controlled } \\
\text { Experiment }\end{array}$ \\
\hline $2 \mathrm{~mm}$ (Sand) & $38.08 \mathrm{~g}$ & $39.26 \mathrm{~g}$ & $64.71 \mathrm{~g}$ & $43.09 \mathrm{~g}$ \\
\hline $0.212 \mathrm{~mm}$ (Silt) & $58.53 \mathrm{~g}$ & $55.51 \mathrm{~g}$ & $34.86 \mathrm{~g}$ & $54.65 \mathrm{~g}$ \\
\hline $0.025 \mathrm{~mm}$ (Clay) & $2.5 \mathrm{~g}$ & $4.1 \mathrm{~g}$ & $0.18 \mathrm{~g}$ & $1.9 \mathrm{~g}$ \\
\hline Resulting Texture & $\begin{array}{l}\text { Silty } \\
\text { Loam }\end{array}$ & $\begin{array}{l}\text { Silty } \quad \text { Clay } \\
\text { Loam }\end{array}$ & Clay & Silty Clay \\
\hline
\end{tabular}

\subsubsection{Moisture Content}

\begin{tabular}{|c|c|c|c|c|c|c|c|c|}
\hline \multirow[t]{2}{*}{ Soil Sample } & \multicolumn{2}{|c|}{ Compost Pit A } & \multicolumn{2}{|c|}{ Compost Pit B } & \multicolumn{2}{|c|}{ Compost Pit C } & \multicolumn{2}{|c|}{ Controlled } \\
\hline & $\mathbf{A}$ & $\mathbf{B}$ & $\mathbf{A}$ & $\mathbf{B}$ & $\mathbf{A}$ & B & $\mathbf{A}$ & $\mathbf{B}$ \\
\hline $\begin{array}{l}\text { Weight of the petri } \\
\text { dish (W1) }\end{array}$ & $\begin{array}{l}42.97 \\
g\end{array}$ & $\begin{array}{l}42.20 \\
\mathrm{~g}\end{array}$ & $\begin{array}{l}43.54 \\
g\end{array}$ & $\begin{array}{l}45.66 \\
g\end{array}$ & $\begin{array}{l}56.83 \\
g\end{array}$ & $\begin{array}{l}47.83 \\
g\end{array}$ & $64.72 \mathrm{~g}$ & $\begin{array}{l}45.60 \\
g\end{array}$ \\
\hline Average & \multicolumn{2}{|c|}{$42.58 \mathrm{~g}$} & \multicolumn{2}{|l|}{$44.6 \mathrm{~g}$} & \multicolumn{2}{|c|}{$52.1 \mathrm{~g}$} & \multicolumn{2}{|l|}{$55.14 \mathrm{~g}$} \\
\hline $\begin{array}{l}\text { Weight of the petri } \\
\text { dish + weight of the } \\
\text { moist soil (W2) }\end{array}$ & $\begin{array}{l}82.97 \\
\mathrm{~g}\end{array}$ & $\begin{array}{l}82.20 \\
\mathrm{~g}\end{array}$ & $\begin{array}{l}83.54 \\
g\end{array}$ & $\begin{array}{l}85.66 \\
g\end{array}$ & $\begin{array}{l}96.83 \\
g\end{array}$ & $\begin{array}{l}87.38 \\
\mathrm{~g}\end{array}$ & $\begin{array}{l}104.72 \\
\mathrm{~g}\end{array}$ & $\begin{array}{l}85.60 \\
g\end{array}$ \\
\hline Average & \multicolumn{2}{|c|}{$82.58 \mathrm{~g}$} & \multicolumn{2}{|l|}{$84.6 \mathrm{~g}$} & \multicolumn{2}{|c|}{$92.10 \mathrm{~g}$} & \multicolumn{2}{|l|}{$95.16 \mathrm{~g}$} \\
\hline $\begin{array}{l}\text { Weight of the petri } \\
\text { dish + weight of the } \\
\text { dried soil (W3) }\end{array}$ & $\begin{array}{l}76.66 \\
\mathrm{~g}\end{array}$ & $\begin{array}{l}76.38 \\
\mathrm{~g}\end{array}$ & $\begin{array}{l}76.99 \\
g\end{array}$ & $\begin{array}{l}80.52 \\
g\end{array}$ & $\begin{array}{l}89.96 \\
g\end{array}$ & $\begin{array}{l}83.40 \\
\mathrm{~g}\end{array}$ & $99.45 \mathrm{~g}$ & $\begin{array}{l}80.79 \\
g\end{array}$ \\
\hline
\end{tabular}




\begin{tabular}{|l|l|l|l|l|}
\hline Average & $\mathbf{7 6 . 5 2} \mathrm{g}$ & $\mathbf{7 8 . 7 5} \mathrm{g}$ & $\mathbf{8 6 . 6 8} \mathrm{g}$ & $\mathbf{9 0 . 1 2} \mathrm{g}$ \\
\hline $\begin{array}{l}\text { Moisture Content }= \\
\text { (W2-W3/W3-W1) } \\
* 100\end{array}$ & $17.85 \%$ & $17.13 \%$ & $15.67 \%$ & $14.4 \%$ \\
\hline
\end{tabular}

\subsubsection{Organic Carbon}

\begin{tabular}{|l|l|l|l|l|c|c|}
\hline Composts & $\begin{array}{l}\mathrm{mL} \text { of Fe2+ Solution } \\
\text { used to titrate sample } \\
(\mathrm{S})\end{array}$ & $\begin{array}{l}\mathrm{mL} \text { of Fe2+ Solution } \\
\text { used to titrate blank } \\
\text { solution } \\
\text { (B) }\end{array}$ & $\begin{array}{l}\text { Milliequivalent } \\
\text { wt. of C in } \\
\text { gram }\end{array}$ & Gram of soil & $\begin{array}{l}\text { moles of } \\
\text { Fe2+( }\end{array}$ & $\begin{array}{l}\text { \% } \\
\text { Carbon }\end{array}$ \\
\hline $\begin{array}{l}\text { controlled } \\
\text { Soil }\end{array}$ & $17.8 \mathrm{~mL}$ & $20 \mathrm{~mL}$ & 0.003 & $0.5 \mathrm{~g}$ & $0.5 \mathrm{M}$ & $\mathbf{2 . 8 \%}$ \\
\hline $\begin{array}{l}\text { Potato } \\
\text { compost }\end{array}$ & $17.2 \mathrm{~mL}$ & $20 \mathrm{~mL}$ & 0.003 & $0.5 \mathrm{~g}$ & $0.5 \mathrm{M}$ & $\mathbf{3 . 4} \%$ \\
\hline $\begin{array}{l}\text { Leaf } \\
\text { compost }\end{array}$ & $17.5 \mathrm{~mL}$ & $20 \mathrm{~mL}$ & 0.003 & $0.5 \mathrm{~g}$ & $0.5 \mathrm{M}$ & $\mathbf{3 . 1} \%$ \\
\hline $\begin{array}{l}\text { Cow dung } \\
\text { compost }\end{array}$ & $16.4 \mathrm{~mL}$ & $20 \mathrm{~mL}$ & 0.003 & $0.5 \mathrm{~g}$ & $0.5 \mathrm{M}$ & $\mathbf{4 . 2} \%$ \\
\hline
\end{tabular}

$$
\% \text { of } C=\frac{(B-S) \times M \text { of Fe } 2+0.003 \times 100}{\text { gof soil }}
$$

\section{Results and Discussion}

\subsection{Soil Color}

The entire compost pit gave a different colored soil as compared to the controlled soil. Our controlled experiment soil with no composting effect was brownish yellow in color. However, after the decomposition of the different compost, the color of the soil has also changed. We found that the Potato compost was yellowish Brown in color, Leaf litter compost with dark brown and the cow dung compost with very dark brown in color. This is because during composting process, the soil and the matter in the pit can undergo homogenization of the color and with humidification due to the outside climate, it could accelerate the decomposition process turning it into brown most of the time and very dark earthy or blackish as well. In the compost pit containing cow dung, it showed favorable results of very dark brown, loose, homogeneous and surprisingly no foul odor at all.

\subsection{Soil $\mathbf{p H}$}

Regarding the $\mathrm{pH}$, every compost pit had a favorable value ranging from 7.1-7.6 which is neutral and there were no significance differences.
According to (Mayes, Batty, Younger, Jarvis, Koiv, Vohla \& Mander, 2009) mature compost such as ours generally has a pH between 6 and 8. It is also concluded that compost microorganisms can operate best under neutral to slightly alkaline conditions. In terms of crop cultivation, they can also thrive in soil conditions that have a neutral $\mathrm{pH}$. The microbial process can also inflict varying changes in $\mathrm{pH}$ values as well. Therefore, we concluded that the soil sample we studied and the different composts we prepared were slightly alkaline and favorable for supporting plant growth.

\subsection{Soil Texture}

The soil texture of the controlled soil (sample soil) was silty clay and upon the decomposition of the different compost, the soil texture has changed. The compost pit with potato peel and leaf litter compost showed silty clay loam texture, while the compost pit with cow dung compost showed clay texture. According to (Brady \& Weil, 2014) the best type of the soil for the agricultural purposes, loamy soils are considered the best soils for the growth of most crops. Soils with a loam textures such as sandy loam, silty loam, clay loam, silty clay loam and loamy sand are a 
combination of soil particle sizes which together provide desirable characteristics. Therefore, we concluded that the potato and leaf litter composts are suitable for the growth of many crops. However, the cow dung compost with clay texture is suitable for growing crops like paddy, which requires a lot of water. Clay soils are rich in nutrients and they possess the ability to retain plenty of moisture which makes it suitable for the growth of paddy.

\subsection{Moisture Content}

Generally the moisture content of the soil ranges from $10 \%$ to $45 \%$, however it depends upon the weather conditions and it may go higher during monsoon seasons (Reynolds, 2006). With reference to the controlled experiment measuring $14.4 \%$ of moisture content, it is evident that the different composting has altered the moisture content. We found out that the potato and leave compost have higher moisture content of $17.85 \%$ and $17.13 \%$ respectively. This is because composting has improved the fertility of soil by transforming the potato peels and leaves in to nutrient rich organic matters. Moreover, research shows that the amount of organic matter in a soil increases the availability of water and increase the water holding capacity of the soil reducing evaporation and runoff (Bonnie, 2018). Similarly, cow dung compost has can also add generous amount of organic matter and improved the moisture holding capacity $(15.67 \%)$. So we can conclude that the different composting has improved the soil moisture content.

\subsection{Organic Carbon}

Soil organic carbon is the most important properties of the soil and it is the basis of soil fertility. It is evident that the organic carbon of soil will increase on addition of different compost. In our experiment, the soil organic carbon of the controlled was found to have $2.8 \%$ of organic carbon and upon the addition of different of composting, it has altered the organic carbon of the soil. The organic carbon of the compost pit with cow dung has the highest organic carbon content with $4.2 \%$ followed by potato compost $(3.4 \%)$ and leaf compost $(3.1 \%)$. The optimum range of soil organic carbon for growing lawns is between 2 to 3 percent and for landscapes and gardens for growing flowers 4 to 6 percent of the organic soil carbon is preferable ( (Clara \& Fatma, 2017). Therefore, we concluded that on addition of different composting the organic carbon of the soil is improved and we found that the cow dung has the highest carbon content in it which makes it more favorable for the growth of crops.

\section{Conclusion}

Regarding our second objective, we have found out that the cow dung composting combination was much faster in the decomposition process then followed by leaf litter and potato peels. The cow dung compost has also shown to have much greater organic carbon for the soil and have the ability to retain many important nutrients for the growth of certain crops such as paddy. Cow dung compost can also be able to hold significant amount of moisture and the color from it represented a favorable dark brown with loose soil aggregates and no unpleasant odor. With regards to $\mathrm{pH}$, every combination of compost has yielded significant results of having neutral scale which is favorable for agricultural practices and plant growth as well.

Overall the process of composting is a very spontaneous process that could have many benefits to the soil structure and its properties. Overall it has led to the sustainability of an area where it could improve waste management by reducing organic wastes from our household in landfills or in municipal waste disposal bins. Therefore, composting prevents a greater number of wastes lying around and encourages natural recycling methods of providing carbon and organic matter to the soil for its fertility, growth and nutrients for crop cultivation and its production as well. Using composting methods has also shown that with good soil quality and its parameter standard has led to the improvement of creating clean and green horticultural practices and the potential for organic agriculture.

\section{Limitations}

During our field experimentation, the decomposition process in the compost pit was very slow due to rainfall and foggy weather that occurred so we had to continuously rely on sunlight and had to come up with an intervention plan to cover the compost pit with sack covers so that we could also let little air to get in. It was unfortunate that we were not able to test temperature and bulk density parameters due to technical irregularities as there were no proper functioning of instruments such as thermometer (Temperature) and Vernier Caliper (Bulk Density) which was important for us to conduct the experiment and come up with more accurate results. 


\section{Bibliography}

[1]. Bender, S. F., Wagg, C., \& Heijden, M. G. (2016). An underground Revolution: Biodiversity and Soil Ecological Engineering fro Agricultural Sustainability. Trends in Ecology and Evolution, 31(6), 440-452.

[2]. Bonnie, L. (2018, 05 04). Gardening. Composting Leaves in Garden: Learn the benefit of Leaf Compost, pp. 91-101.

[3]. Brady, N. C., \& Weil, R. R. (2014). The Nature and Properties of Soils (14th ed.). Pearson Education Inc.

[4]. Brevik, E. C., Cerda, A., Mataix-Solera, J., Pereg, L., Quinton, J. N., Six, J., et al. (2015). The Multidisciplinary Nature of Soil. Soil, 1, 117-129.

[5]. Chan, K. Y. (2001). Soil Particulate Organic Carbon Under Different Land Use and Management. Soil Use and Management, 17(4), 217-221.

[6]. Clara, L., \& Fatma, R. (2017). Soil organic carbon the hidden potential. Rome, Italy: Food and Agriculture Organization of the United Nations.

[7]. Cooperband, L. R. (2000, June). Composting: Art and Science of Organic Waste Conversion to a Valuable Soil Resource. Laboratory Medicine, 31(6), 283-289.

[8]. Davidson, E. A., \& Janssens, I. A. (2016, March 09). Temperature Sensitivity of Soil Carbon Decomposition and Feedbacks to Climate Change. Nature, 165-173.

[9]. Epstein, E. (1997). Science of Composting . Lancaster, U.S.A.: Technomic Publishing Company.

[10].Hayat, R., Ali, S., Amara, U., Khalid, R., \& Ahmed, I. (2010). Soil Beneficial Bacteria and theirRole in Plant Growth Promotion: A Review. Ann Microbiol, 60, 579-598.

[11].Jiang, C., Wang, X., Haiyan, Z., Labzovskii, L., \& Liu, T. (2019, July). Re-orienting Ecological Restoration in Degraded Drylands for a More Sustainable Soil-Water Relationship: Non-linear Boundary of Limited Water Resourcs in Combating Soil Loss. Journal of Arid Environments, 167, 92-106.

[12].Jones, C. A. (1983). Effects of Soil Texture on Critical Bulk Densities for Root Growth. Soil
Science Society of America Journal, 47(6), 12081211.

[13].Keesstra, S. D., Bouma, J., Wallinga, J., Tittonell, P., Smith, P., Cerda, A., et al. (2016). The Significance of Soils and Soil Science Towards Realization of the United NAtions Sustainable Development Goals. Soil, 2, 111-128.

[14].Lang, N. L., \& Smith, S. R. (2007, April 19). Influence of Soil Type, Moisture Content and Biosolids Application on the Fate of E-coli in Agricultural Soil Under Controlled Laboratory Conditions. Journal of Applied Microbiology, 103, 2122-2131.

[15].Mayes, W., Batty, L., Younger, P., Jarvis, A., Koiv, M., Vohla, C., et al. (2009). Wetland Treatment at Extremes of pH: A Review. Science of the Total Environment, 407(13), 3944-3957.

[16].Melville, M. D., \& Atkinson, G. (1985). Soil Colour: Its Measurement and Its Designation in Models of Uniform Colour Space. Journal of Soil Science, 36(4), 495-512.

[17].Nakasaki, K., Shoda, M., \& Kubota, H. (1985). Effect on Temperature on Composting of Sewage Sludge. Applied and Environmental Microbiology, 1526-1530.

[18].Perk, M. v. (2013). Soil and Water Contimination. London: Taylor and Francis.

[19].Quine, T. A., \& Zhang, Y. (2002). An Investigation of Spatial Varation in Soil Erosion, Soil Properties, and Crop Production within an Agricultural Field in Devon, United Kingdom. Journal of Soil and Water Conservation, 57(1), 55-65.

[20]. Reynolds, S. (2006). The Gravimetric Method of Soil Moisture Determination Part III. Journal of Hydrology, 288-300.

[21].Stevens, R. J., Laughlin, R. J., \& Malone, J. P. (1998). Soil pH Affects the Processes Reducing Nitrate to Nitrous Oxide and Di-nitrogen. Soil Biology and Biochemistry, 30(8-9), 1119-1126.

[22].Williams, R., Ahuja, L., \& Naney, J. (1992). Comparison of Methods to Estimate Soil Water Characteristics from Soil Texture, Bulk Density, and Limited Data. Soil Science, 153(3), 172-184.

[23].Wolters, V. (2001). Biodiversity of Soil Animals and its Function. European Journal of Soil Biology, 37, 221-227. 